\title{
В.А. Ваньков
}

В преддверии недавних выборов в Государственную Думу РФ часто можно было услышать, что результат их полностью предрешен: произошедшие за последние годы сдвиги в российской политике, а также изменение конфигурации электорального пространства страны (объединение двух “партий власти” образца 1999 г. под эгидой “Единой России” и инициированный президентской администрацией раскол левых) делают неизбежной уверенную победу нового кремлевского “монолита", а это, в свою очередь, создаст почву для закрепления выгодного исполнительной власти расклада сил и консервации нынешнего квазиреформаторского политического курса. Безусловно, подобный прогноз имеет под собой серьезные основания, тем не менее ряд глубинных тенденций в динамике электорального процесса, проявившихся на предыдущих парламентских выборах, указывает на возможность и иного сценария развития событий. Как бы то ни было, некоторые закономерности пространственного распределения электоральной поддержки субъектов, представляющих важнейшие направления политико-идеологического "раскола" ведущих социальных групп страны, свидетельствуют о наличии в складывающейся электоральной культуре российского социума определенных “ограничений” для манипулятивного воздействия и административного давления.

Данная статья готовилась до парламентских выборов декабря 2003 г., и ее статистической базой послужили материалы думских кампаний 1995 и 1999 гг. Однако указанное обстоятельство, как нам кажется, не снижает актуальности и теоретической значимости проделанной работы: действие механизма формирования избирательских предпочтений, который был выбран в качестве объекта для изучения, носит долгосрочный характер и довольно устойчиво к влиянию других детерминант, определяющих электоральный выбор. Это позволяет надеяться, что полученные в ходе исследования выводы не только найдут подтверждение в результатах декабрьских выборов, но и будут способствовать дальнейшей разработке теоретических моделей электорального процесса в нашей стране.

Изучение системы политических предпочтений избирателей в рамках так наз. "социокультурного" (или “социологического") подхода, согласно которому поведение избирателей в значительной мере детерминировано их принадлежностью к большим социальным группам и присущими таким группам ценностными установками, имеет давние традиции [см., напр. Lazarsfeld et al. 1954; Lipset, Rokkan 1967; Колосов, Туровский 1996; Колосов и др. 1997; Политический альманах 1997; Весна-99 1999; Овчинников 2000]. Данный подход ориентирован на выявление устойчивых компонентов электорального поведения, обеспечивающих его относительную стабильность, - в противоположность "ситуативной” направленности другого подхода, известного как “экономическое голосование”.

Признавая неполноту и ограниченность обоих подходов, мы все же сделаем упор на том из них, который позволяет находить детерминанты, придающие стабильность пространству идейно-политических предпочтений и препятствующие воздействию на поведение избирателей факторов ситуативного

ВАНЬКОВ Василий Александрович, аспирант ИСП РАН. 
порядка (динамики экономического положения - индивидуального и/или страны в целом, применения манипулятивных технологий, изменения политической конъюнктуры и т.п.). Вернее, мы будем учитывать отклоняющее влияние перечисленных факторов, признавая при этом их несамостоятельное, подчиненное положение по отношению к фактору “системному”.

В качестве параметра, отражающего один из важнейших социокультурных кливажей на уровне больших групп, нами взят такой показатель, как доля городского населения в поселенческой структуре избирательного округа. Разумеется, указанное социально-демографическое различение не описывает всего многообразия существующих в обществе социальных групп, которые могут выделяться по самым разным основаниям (материальное благосостояние, статус, положение в системе общественного производства, этническая принадлежность, возрастные и гендерные характеристики и т.д.). Более того, некоторые из этих групп служат весьма значимыми факторами самоидентификации людей и потому выступают мощными средствами политической мобилизации. Тем не менее имеются два обстоятельства, которые оправдывают акцент на данном параметре при анализе механизма формирования электоральных предпочтений. Во-первых, исследователю недоступна статистическая информация по некоторым демографическим и социально-экономическим показателям в "разрезе" избирательных округов (по доле городского населения такая статистика существует) [Политический альманах 1997: 448-455], уровень же регионов непригоден для точного статистического анализа, так как здесь стираются и становятся незаметными различия в голосовании представителей больших социальных групп. Во-вторых, принадлежность избирателя к городской или сельской культуре является комплексным признаком, включающим в себя ряд других. Так, например, известно, что горожане превосходят сельское население по уровню образования, среди них меньше процент пожилых людей, они сильнее вовлечены в современные сектора экономики и в среднем обладают более высокими статусными позициями (хотя все это касается главным образом жителей столиц и региональных центров).

С точки зрения доли городского населения избирательные округа можно разделить на шесть групп: (1) “аграрные” (до 50\% городского населения); (2) “преимущественно аграрные" (50-65\% городского населения); (3) "смешанные среднегородские" (65-85\% городского населения); (4) "смешанные крупногородские" (85-95\% городского населения); (5) "преимущественно городские" (95-100\% городского населения); (6) “исключительно городские" (100\% городского населения). Подобная типологизация представляется вполне правомерной, ибо она говорит о целом ряде важных социально-демографических параметров. Социально-экономическая статистика убедительно свидетельствует: по мере увеличения размера населенного пункта (и повышения его политико-административного статуса) возрастают образованность населения (а соответственно - уровень социальной саморефлексии), степень приобщенности его к современным СМИ и вовлеченности в рыночную экономику, меняется специфика потребностей (сдвиг в сторону ценностей так наз. "постиндустриального" общества) и понижается плотность “социальных сетей”. Все это, в свою очередь, предопределяет большую свободу гражданина при принятии электорального решения.

Для изучения электорального процесса на уровне избирательного округа построим линейные регрессионные однофакторные модели на статистическом материале выборов депутатов Государственной Думы РФ 17 декабря 1995 г. и 19 декабря 1999 г. в части голосования за федеральные партийные списки и сопоставим вычисленные по результатам обеих кампаний коэффициенты корреляции (r) с помощью методов сравнительного анализа. Это даст возможность определить степень устойчивости распределения избирательной поддержки в контексте территориальной структуры российского электорального пространства.

Вычисления проводились по всем 224 округам (кроме Чеченского одномандатного избирательного округа № 31), а также еще на нескольких статистических базах: (1) республики; (2) автономные округа; (3) края, области; (4) 
края, области, Москва и Санкт-Петербург, (5) Москва и Санкт-Петербург. Три последних группы могут быть условно названы "русскими" - в отличие от республик и автономных округов как национальных образований со значительной долей “титульного” населения (хотя в некоторых АО и республиках она существенно ниже 50\%). Классификация округов по этническому составу населения необходима для учета возмущающего воздействия этого фактора на электоральное поведение.

Рамки работы сознательно ограничены анализом итогов голосования за федеральные партийные списки в ходе думских выборов 1995 и 1999 гг. На президентских выборах и при голосовании за депутатов-одномандатников электоральное решение, как правило, более персонифицировано, что не позволяет избирателям в полной мере проявить свои политические предпочтения. Результаты парламентских выборов 1993 г. не были включены в поле исследования в связи с их недостаточной репрезентативностью в плане представительства ведущих политических сил (как известно, часть “левых" и “национал-патриотов” оказалась лишена возможности принять в них участие). К тому же эти выборы носили учредительный характер, а на поведение избирателей продолжали влиять последствия недавнего политического кризиса.

В целях большей сопоставимости регрессионные однофакторные модели строились по единой методике. Прежде всего были вычислены коэффициенты корреляции между двумя признаками - результативным (процент голосов, поданных за партии, добившиеся наибольшего электорального успеха, а также за блоки партий сходной идеологической ориентации) и факторным (доля городских жителей в населении округа). Величина коэффициента корреляции фиксирует количественные показатели зависимости результативного признака от факторного и позволяет оценивать степень соответствия уравнения регрессии* выявленным причинно-следственным связям. Знак коэффициента корреляции отражает качество этой зависимости: “+” указывает на прямую зависимость, "-" - на обратную.

Как известно, значимыми являются коэффициенты корреляции (r), абсолютное значение которых превосходит 0,2 [Орлов, Шумпетов 2001]. Незначимые $\mathrm{r}$ говорят о том, что мы не можем, исходя из имеющихся данных, достоверно установить связь социально-демографического показателя и результатов голосования за данную партию.

При обращении к итогам первых свободных выборов в РФ сразу же бросается в глаза безусловная зависимость между местом проживания избирателя и характером его голосования: “левые” оппозиционные силы (коммунисты и национал-патриоты на парламентских выборах и Г.Зюганов - на президентских) получали существенный перевес в южных аграрных регионах, тогда как в северных, наиболее урбанизированных и промышленно развитых, побеждали преимущественно “демократы” (“Выбор России” в 1993 г., ДВР, “Яблоко”, НДР в 1995 г. и Б.Ельцин в 1996 г.) [Колосов и др. 1997]. Но исход парламентских выборов 1999 г. внес сушественные коррективы в сложившиеся представления о географической структуре идеологического "раскола" России на "правых" (индустриальный Север и Дальний Восток, ориентированные на продолжение реформ) и “левых" (аграрный юг европейской части России и Сибирь с их консервативно-охранительными установками). Результаты этих выборов, казалось, свидетельствовали о сближении "сельского" и “городского" электоральных полюсов.

${ }^{*} r=\frac{\overline{x y}-\bar{x} \cdot \bar{y}}{\sigma}$, где $\sigma_{\mathrm{X}}-$ среднее квадратическое отклонение (с.к.о.) фактора $x$ (процент городского населения) ; $\sigma_{\mathrm{y}}-$ с.к.о. процента голосов, отданных за данную партию;

$\bar{x}$ и $\bar{y}-$ средние величины процента городского населения и процента голосов, отданных за данную партию ; $\overline{x y}-$ средняя величина произведений процента голосов и процента городского населения. 
Чтобы более достоверно определить характер и степень устойчивости факторов, лежавших в основе выявленной динамики, мы сопоставили коэффициенты корреляции и средний процент голосов, отданных за ту или иную партию в избирательных округах шести уровней урбанизации. В качестве результативного признака выступала степень поддержки избирателями (в \%) ведущих идеологических групп. В этих целях российский политико-идеологический континуум был условно поделен нами на пять частей: (1) “левые” (в 1995 г. - КПРФ, КТРСС и АПР, в 1999 г. - КПРФ, КТРСС и “Сталинский блок"); (2) “центристы” (в 1995 г. - “Женщины России", Партия самоуправления трудящихся, Блок Ивана Рыбкина и ПРЕС, в 1999 г. - “Женщины России", Партия пенсионеров и ОВР); (3) “партия власти” (в 1995 г. - НДР, в 1999 г. “Единство”); (4) “патриоты-державники” (в 1995 г. - ЛДПР, КРО и “Держава", в 1999 г. - Блок Жириновского, КРО и движение "В поддержку армии”); (5) “либералы” (в 1995 г. - "Общее дело", ДВР-ОД, "Вперед, Россия!", Партия экономической свободы и “Яблоко", в 1999 г. - “Яблоко" и СПС).

Структурирование электорального пространства посредством наложения своего рода "сетки координат", задаваемой сложившейся системой политикоидеологических ценностей и ориентаций, - традиционный и необходимый аналитический инструмент изучения характера и динамики поведения избирателей. Подобная модель предполагает наличие, с одной стороны, некоего набора идеологических позиций и соответствующих “предложений”, а с другой - системы политических предпочтений граждан. Процесс соотнесения предлагаемых избирателю вариантов политической самоидентификации с существующими на момент принятия электорального решения политическими предпочтениями и обусловливает динамику электорального поведения. Приведенная классификация, на наш взгляд, максимально полно отражает типы политико-идеологической идентичности, с которыми может отождествлять себя избиратель, делая выбор между представленными на электоральном "рынке" акторами.

Наиболее близки - и в смысле социальной базы, и в плане принадлежности к единой политической субкультуре - первый (“левые”) и четвертый (“патриоты-державники”) блоки. Их электоратам присущи традиционный тип ментальности, негативное отношение к реформам (и переменам вообще), доминирование общинных коллективистских ценностей, этатизм, ориентация на "сильную руку", а также протестный характер голосования. Не случайно многие из включенных в эти блоки партийных организаций на протяжении долгого времени входили в НПСР - широкую коалицию сил консервативнопротестной ориентации. Вместе с тем ряд отличий в установках двух сегментов политико-идеологического спектра не позволяет объединить их электораты в одну группу. Так, “левые” партии апеллируют прежде всего к ценностям коммунистического прошлого, для них не слишком важны этнонациональная идентичность и националистическая идеология, имеющие ключевое значение для "национал-патриотов" с их ориентацией на возрождение "великорусского" этноса. В мировоззрении "патриотов" важное место занимает защита национальной самобытности - в противовес как "антинациональному" коммунистическому режиму, так и западной модернизационно-рыночной модели. Как следствие, в идеологическом “обеспечении” их политических кампаний особое внимание уделяется проблематике национально-государственного строительства.

В сфере экономики "патриоты" более умеренны, нежели “левые", - они выступают за национальный вариант социально-политической модернизации (впрочем, в последние годы это различие в программных установках постепенно сглаживается). В риторике же “левых" делается акцент на социальной справедливости и усилении роли государства в перераспределении материальных благ и прочих ресурсов.

На другом конце политико-идеологического спектра находятся "либералы”, ориентированные на ценности индивидуализма и выступающие за про- 
должение демократических реформ, направленных на построение постиндустриального общества по западному образцу. В их идеологии и риторике главные понятия - “права человека", “правовое государство”. Воплощение в жизнь идей “либералов” предполагает максимальное сокращение регулятивных полномочий государства в экономике и качественное уменьшение его вмешательства в деятельность институтов гражданского общества. В то же время внутри данного блока нужно различать “радикал-либералов” (СПС) и “социально ориентированных" либералов ("Яблоко”).

Что касается "центристов" и “партии власти", то позиционирование их в рамках политико-идеологического континуума происходит отнюдь не на идеологической основе. Напротив, их место между двумя группами сил определяется как раз отсутствием четких установок по многим из перечисленных выше программных целей. Но если неопределенность идеологической идентификации электората “центристов" обусловлена промежуточным положением (на границах социокультурных “разломов”), которое занимают образующие его социальные группы, то отсутствие идеологических предпочтений у электората "партии власти” имеет другую природу. Оно объясняется, с одной стороны, повышенной конформностью этой части электората и ее склонностью к поддержке любых действий власти ("колеблется вместе с генеральной линией партии"), а с другой - наличием в ее составе социальных групп, выступающих не за продолжение реформ и не за реставрацию прежних социальноэкономических устоев, а скорее за сохранение статус-кво. Вместе с тем избиратели "центристского" толка являются главным электоральным ресурсом “партии власти”, которая, как свидетельствует опыт думских кампаний, может позиционировать себя в качестве и правоцентристской (НДР в 1995 г.), и левоцентристской (“Единство” в 1999 г.) силы.

Разумеется, предложенная классификация довольно условна. В частности, нетрудно заметить, что некоторые акторы занимают в ней двоякое положение: то же "Единство" можно квалифицировать и как "партию власти", и как "центристов"; а илюхинское движение "В поддержку армии" идеологически (и организационно) вполне вписывается в коммунистический сегмент идеологического спектра. Но подобное "сидение на двух стульях" - весьма популярный среди участников “большой” российской электоральной гонки тактический прием, нацеленный на расширение политической базы.

Статистический анализ динамики поведения избирателей в $1995-1999$ гг. показал, что средний (по округам всех типов) процент проголосовавших за “партию власти” в лице “Единства" вырос в 2,3 раза (с 10,13\% до 23,3\%). Причем коэффициент корреляции с долей горожан в населении округов поменял свой знак с положительного (+0,24 у НДР в 1995 г.) на отрицательный (-0,36 у “Единства" в 1999 г.). Следовательно, своим успехом партия президента была обязана главным образом сельскому электорату. При этом обращает на себя внимание тот факт, что и по доле проголосовавших, и по характеру связи с городским населением округов $(+0,15)$ ОВР оказалось гораздо ближе к положению так наз. "партии власти", нежели “Единство”. Резонно предположить, что многие избиратели видели “партию власти”, стремящуюся сохранить статус-кво, именно в ОВР. Ведь первые места в избирательном списке объединения занимали ведущие политики “федерального уровня”, и в его поддержку выступили некоторые областные и республиканские лидеры, активно использовавшие при этом свой “административный ресурс". (Стоит заметить, что “Единство” также задействовало “административный ресурс" лояльных ему глав субъектов РФ, представлявших преимущественно слабые в экономическом отношении регионы-реципиенты.)

"Центристы" и “либералы” в целом сохранили специфику своей социальной базы. Об этом свидетельствует количественное и качественное постоянство связи этих блоков с долей городского населения (r “центристов-95" $+0,23 ; \mathrm{r}$ "центристов-99" - + 0,17; r "либералов-95" - + 0,74; r “либералов-99" - $+0,77)$. Необходимо заметить, что такая картина получается без учета рег- 
рессионной связи “Единства" (r $-0,36)$. При включении последнего в число “центристов" ситуация полностью “переворачивается", что дает основания говорить о существенном “полевении" “центра" в социально-географическом смысле (в 1995 г. ни у одной из партий этого направления не было отрицательного показателя корреляции с рассматриваемым факторным признаком).

Таким образом, наибольшую степень однородности и устойчивости социальной базы по данному факторному признаку демонстрируют “правые". Электоральная поддержка “либералов” осталась почти на прежнем уровне, если иметь в виду их ведущих представителей (СПС и “Яблоко”). С учетом же голосов, отданных за "карликовые” партии демократической ориентации образца 1995 г., можно констатировать утрату “правыми” 2-3\% избирателей. На ту же долю “похудела" и левая часть политико-идеологического спектра, но не столько вследствие потерь “радикалов” (КТРСС), избиратели которых, по всей видимости, перешли к КПРФ, сколько из-за оттока электората АПР. Одновременно ослабла отрицательная корреляция “левых” с долей городского населения (-0,65 в 1995 г. и $-0,53$ в 1999 г.).

Только "центристам" удалось добиться резкого повышения уровня электоральной поддержки - в 1,6 раз (и это без "центристского" по сути "Медведя", с которым они получают почти четырехкратное увеличение). В данной связи следует отметить, что одним из важнейших “источников” пополнения электорального корпуса ОВР и “Единства" стали избиратели, голосовавшие в 1995 г. за "малые" “центристские” партии и движения (“Женщины России", ПСТ, Блок Ивана Рыбкина, ПРЕС и др.).

Анализ электоральной динамики показывает, что в 1999 г. “патриоты” и "партия власти” как бы поменялись местами: в 1995 г. тогдашняя “партия власти" - НДР находилась на последнем по уровню электоральной поддержки месте, а консервативно-протестные силы, представленные ЛДПР, КРО и “Державой”, - на втором. Четыре года спустя второе место заняла новая версия “партии власти” в лице “Единства”, тогда как “патриоты” скатились на пятое. Если же принять во внимание, что там, где "административный ресурс" не был задействован в пользу других партий, конформистски настроенный электорат отошел к ОВР, в отличие от “Медведя" не имевшей статуса "партии власти", справедливо говорить не об увеличении электоральной базы последней, а о существенном росте “центристской" части и ее доминировании в электоральном пространстве на фоне снижения "веса" остальных идейнополитических блоков.

Электорат “партии власти” в “чистом виде” (те, кто проголосовал за ОВР) практически сохранил положительный характер связи с городской субкультурой (+0,24 у НДР в 1995 г. и +0,15 у ОВР в 1999 г.). Некоторое уменьшение коэффициента корреляции объясняется тем, что в суммарный показатель по стране входят и данные по республиканским округам с “управляемым" электоратом (r - $-0,27)$. В краевых и областных (так наз. "русских") округах корреляционная связь с долей городского населения у НДР-95 и ОВР-99 примерно одинакова $(+0,59$ и $+0,48$,соответственно), что свидетельствует об устойчивости основной социокультурной характеристики этой части электорального пространства. Небольшое преимущество НДР получило здесь лишь за счет поддержки населения городских округов, без учета Москвы и Санкт-Петербурга.

ОВР демонстрирует наивысший уровень концентрации электората. На четырех главных электоральных “доноров” объединения (Татарстан, Башкортостан, Москва и Московская область) пришлось около 45\% всех избирателей, поддержавших его по стране в целом, что указывает не только на высокую степень пространственной локализации, но и на узость социальной базы. Достаточно сказать, что, будучи самой “городской” партией, ОВР смогло победить лишь в Москве, проиграв своим главным конкурентам - "Единству", КПРФ и СПС - даже там, где его интересы “лоббировали” местные политические лидеры (в Санкт-Петербурге, Казани и Уфе). Для сравнения: традиционно считавшаяся ориентированной на село КПРФ в 1999 г. улучшила свои 
показатели, заняв первое место по уровню поддержки в больших городах и победив в 9 из 20 мегаполисов.

Среднестатистический социально-демографический “портрет” избирателя “партии власти” таков: это житель большого города, принадлежащий к старшей возрастной группе, с высшим образованием и средними доходами. Разумеется, названными характеристиками обладает лишь часть электората данной партии, без ее “контролируемого сегмента" в виде компактно проживающего сельского населения "титульной" национальности в республиках и АО.

Что касается таких важных компонентов электорального поведения, как динамика активности избирателей и голосование “против всех", то в этом смысле выборы 1999 г. продемонстрировали некоторые подвижки в сторону сближения городского и сельского электоратов по уровню явки. Голосование “против всех" выросло незначительно $(0,5 \%)$ при заметном увеличении положительной корреляции с городом (г 1995 г. — +0,2; r 1999 г. - +0,6).

$$
* * *
$$

Изложенные выше предварительные результаты исследования, безусловно, нуждаются в верификации, поскольку, повторим, классификация по принципу “левые”, “правые”, “либералы" и т.д. довольно условна и не всегда отражает подлинную картину электоральных предпочтений. Несмотря на наличие сходных черт в риторике и идеологическом “обосновании” своей деятельности, конкретные политические акторы - партии, движения, объединения - могут по-разному позиционироваться в сознании избирателей, а вектор динамики крупного идеологического блока складывается как равнодействующая векторов входящих в его состав сил. Однофакторная модель не способна полностью описать динамику поведения избирателей. Поселенческая структура - фактор, имеющий стабильный долговременный характер (вследствие относительного постоянства и малой изменяемости во времени), он объясняет в первую очередь устойчивые компоненты в структуре электорального поведения. На практике же последнее является результатом взаимоналожения долговременных факторов (специфика социализации индивида, в т.ч. его принадлежность к большим социальным группам с особой политической культурой) и детерминант конъюнктурно-ситуативного порядка (динамика материального положения, позиции местных властей, воздействие политической пропаганды и др.).

В свете этого представляется целесообразным, используя методы статистического анализа двух рядов зависимой переменной (итоги голосований на парламентских выборах 1995 и 1999 гг.), проследить динамику электорального поведения на уровне отдельных партий в контексте воздействия трех факторных переменных, в совокупности объясняющих, на наш взгляд, большую часть вариаций голосования в избирательных округах. Это - тип поселенческой структуры, “административный ресурс” и уровень социально-экономического развития территорий.

Для начала посмотрим, как отражается влияние этих факторов на динамике электоральной поддержки КПРФ - главной оппозиционной федеральным властям силы “слева", актуализировавшей биполярный "раскол” в структуре электорального пространства на уровне территориальных единиц. Как уже отмечалось, корреляция между голосованием за КПРФ и степенью урбанизации в 1999 г. попрежнему была отрицательной, абсолютная величина $\mathrm{r}$ изменилась несущественно (-0,22 в 1995 г. и -0,18 в 1999 г.). В округах же с преобладанием русского населения (края и области) она, наоборот, увеличилась (-0,5 в 1995 г. и -0,7 в 1999 г.). Если мы обратимся к такому показателю, как “прирост доли” (т.е. удельного веса отдельного элемента в данной структуре по отношению к изменению структуры в целом), то увидим, что в аграрных и преимущественно аграрных округах этот показатель имеет отрицательное значение $(-0,5 \%$ и $-4 \%$, соответственно).

Теперь попытаемся проследить динамику “прироста доли" в округах, различающихся по поселенческой структуре и позиции главы исполнительной власти региона по отношению к ключевым субъектам, конкурирующим в 
идейно-политическом пространстве. Подобное “наложение” детерминант позволит, с одной стороны, сопоставить их эвристический потенциал и валидность, а с другой - подтвердить (или опровергнуть) предположение о наметившемся сближении "красного” и “синего" (продемократического) политических пространств России.

Анализ данных о преимущественно аграрных округах обнаруживает, что наибольшего “прироста доли" КПРФ удалось достичь в тех регионах, главы администраций которых так или иначе поддерживали эту партию: средний процент проголосовавших за КПРФ от числа участников выборов увеличился там на $8 \%$, а “прирост доли” составил $+21,6 \%$. В то же время в аналогичных округах регионов, чьи лидеры занимали нейтральную позицию или же представляли конкурирующие с КПРФ силы (“Единство”, ОВР, СПС), количество проголосовавших за коммунистов выросло лишь на $1 \%$.

В преимущественно городских “русских" округах, контролируемых “красными” губернаторами и близкими к “левым" национал-патриотами (Краснодарский край, Ростовская область), голосование за КПРФ в период с 1995 по 1999 г. увеличилось на 1,9\%, а “прирост доли” оказался отрицательным $(-0,7 \%)$. В округах того же типа, но в регионах, известных своей прореформаторской ориентацией, средний процент проголосовавших за коммунистов увеличился на 3 пункта, что дало “прирост доли" $+6 \%$.

Ясно, что определенное сближение "красного" и “синего" полюсов действительно имело место, но главным образом в “синих" регионах, причем темпы прироста доли голосов, отданных за КПРФ, в аграрных округах были ниже, чем в городских. Поэтому правомерно вести речь не столько о стирании различий между регионами, взятыми в качестве неких электоральных "монолитов", сколько о сравнительном взаимном выравнивании (в "синих" субъектах РФ) составляющих их субкультур - при заметном воздействии "административного фактора" на динамику голосования.

Интересно складывалась электоральная ситуация и в автономных округах. В этих субъектах РФ роль “поставщика" новых голосов в 1999 г. сыграли “центристы” образца 1995 г. ("Женщины России" и ПСТ), а также "патриоты” из КРО. Большая часть их электората, по-видимому, “ушла” к “Единству": налицо положительная связь между снижением уровня электоральной поддержки названных объединений и успехом “партии власти” в соответствующих округах в 1999 г. Вектор “перетекания” голосов здесь, как и в целом по стране, зависел от двух обстоятельств - степени урбанизации округов и позиции местных лидеров.

Стоит отметить, что в автономных округах устойчивой зависимости между уровнем жизни и голосованием за “системную оппозицию” в лице КПРФ не просматривается. В трех наиболее депрессивных в социально-экономическом отношении субъектах РФ - Корякском, Эвенкийском и Чукотском АО, - которые по логике “экономического голосования" должны были бы поддержать коммунистов, динамика КПРФ оказалась наихудшей среди автономных округов $(+0,06 \%)$. Напротив, наивысших показателей тут добилась “партия власти" ("Единство") - 42\%.

Эти особенности выбора, как нам кажется, обусловлены наложением двух, казалось бы, разнонаправленных тенденций. Во-первых, уязвимые в социальном и экономическом плане группы избирателей склонны к протестному голосованию, между тем путинская “партия власти” воспринималась многими не как сила, выступающая за экономическое и политическое статус-кво, но как новое движение, обладающее значительным реформаторским потенциалом (не в либеральной, а в “государственно-патерналистской" его версии). Во-вторых, электоральному поведению жителей сел, “малых" городов и так наз. поселков “городского типа" (“переходный тип” электората) в принципе присущ повышенный уровень конформизма, а во всех трех перечисленных автономных округах главы исполнительной власти открыто поддерживали “Единство". 
Рассмотрим влияние фактора уровня жизни на электоральное поведение россиян более подробно. В рамках упоминавшегося выше "экономического" подхода уровень жмзни граждан и динамика их материального благосостояния трактуются как структурообразующие элементы в механизме формирования электоральных предпочтений. Согласно этому подходу, избиратели обычно поддерживают ту силу, с победой которой связывают улучшение своего (или страны/региона в целом) материального положения.

К сожалению, необходимая для проверки данной гипотезы социально-экономическая статистика на уровне избирательных округов РФ недоступна. Тем не менее можно, используя представленную выше методику, проследить, как влияет уровень социально-экономического благополучия регионов на динамику голосования в округах с различной поселенческой структурой. В центре внимания опять окажутся КПРФ и "Единство" как самые значимые “аттракторы”. Конкуренция между ними в борьбе за “центристский” электорат явилась скрытым источником “передела" электорального пространства, что, соответственно, отразилось на динамике предпочтений избирателей.

При решении этой исследовательской задачи целесообразно обратиться к сводным “индексам социального благополучия" за 1999 г., разработанным экспертами Московского центра Карнеги [Регионы 2001: 82-107]. В основу таких "индексов" были положены следующие социально-экономические показатели: (1) коэффициент младенческой смертности; (2) уровень безработицы; (3) миграционная убыль населения; (4) уровень преступности; (5) объем задолженности по заработной плате; (6) покупательная способность населения (как соотношение среднедушевого дохода к прожиточному минимуму в регионе). Полученные данные позволили разделить российские регионы на две группы: социально благополучные (среднее значение индекса $-0,5-0,75$ ) и социально неблагополучные (среднее значение индекса - 0,75-1,5).

В каждую из выделенных групп вошли регионы с разными поселенческими структурами, представляющие неодинаковые политические субкультуры. Средняя доля городского населения в неблагополучных регионах составила $61,3 \%$, что на $10 \%$ ниже, чем аналогичный показатель в относительно преуспевающих регионах. Это подтверждает предположение о том, что социальноэкономическое развитие в урбанизированных округах несколько выше, чем в аграрных (при всей условности 10-процентной разницы). Следует иметь в виду и то, что “разрыв” был бы гораздо значительнее, если бы в качестве территориальной “единицы” мы взяли не крупный регион, включающий в себя как высокоразвитые городские округа, так и депрессивные аграрные, а, скажем, городские и сельские поселения в отдельности.

Как ни парадоксально, но анализ голосования на выборах 1999 г.* обнаруживает, что в неблагополучных регионах КПРФ пользуется меньшей поддержкой $(21,9 \%)$, чем в благополучных $(26,1 \%)$. На уровне избирательных округов электоральная ситуация несколько выравнивается, но все равно остается неожиданной: в высокоразвитых регионах в округах с долей городского населения выше среднего (средний показатель для регионов данного типа $-76,5 \%$ ) коммунисты получили $18,7 \%$ голосов, а там, где эта доля ниже, $-28,6 \%$; в “депрессивных" регионах в округах с долей городского населения выше среднего (средний показатель - 73,5\%) им досталось $22,3 \%$ голосов, а там, где она ниже среднего, - 29,3\% голосов.

Полученные результаты позволяют сделать два вывода. Первый довольно тривиален: регионы неоднородны по уровню социально-экономического развития, что находит отражение в структуре поведения избирателей. Второй менее конвенционален: на дифференциацию итогов голосования влияет не столько благополучие округа (для округов, выделенных по показателю социального благополучия, дисперсия, т.е. "разброс", в итогах голосования дости-

\footnotetext{
* Для устранения социологических “шумов” и нейтрализации такого фактора, как администра-
} тивное влияние, из рассмотрения были исключены национальные образования. 
гает $8,4 \%$ ), сколько его принадлежность к городской или сельской субкультуре (дисперсия - 2\%). Несколько иную картину дает статистический анализ голосования за "Единство": в “аграрных" округах его поддержали 18\% избирателей, в “преимущественно аграрных" - 26,7\%, в “смешанных" - 28,5\%, в “преимущественно" и “исключительно городских" - 30\%. Здесь зависимость поведения избирателей от уровня жизни заметно выше: если по данному параметру дисперсия составляет 5\%, то по параметру поселенческой структуры 7\%. Это говорит об относительно большей релевантности и объяснительной ценности первого фактора. Выявленные различия еще раз подтверждают принципиальную разницу между электоратами двух партий: электоральная база КПРФ сравнительно устойчива именно в силу “привязанности” к сельской субкультуре; электорат "Единства" размыт в социокультурном плане, его объединяет разве что протестный характер голосования представителей тех общественных групп, которые находятся в состоянии социальной депривации (безработные молодого и среднего возраста, со средним специальным образованием, проживающие в небольших и средних городах). Эта особенность названных групп делает их крайне уязвимыми для манипулятивного воздействия, превращая в объект острой борьбы со стороны конкурирующих политических сил. Их голоса и обеспечили ошеломляющий успех “Единства” в 1999 г., когда "партия власти" отказалась от четкого и однозначного самоопределения в системе "идеологических координат" и, позаимствовав популистскую риторику консерваторов-почвенников, встала на путь политического прагматизма.

Таким образом, проведенное исследование дает основания для ряда заключений и прогнозов.

1. В перспективе неизбежно произойдет сокращение числа электорально значимых субъектов, обладающих массовой поддержкой. Накопив в ходе предшествовавших электоральных циклов опыт принятия электоральных решений, избиратели будут с гораздо большей осторожностью “тратить” свои голоса, направляя их прежде всего на поддержку политических сил, имеющих шансы преодолеть 5-процентный барьер. Об этом говорит отток электората так наз. “малых" партий: если в 1995 г. за подобные политические образования было отдано свыше половины голосов избирателей, то в 1999 г. - почти в два раза меньше. Думается, тенденция к снижению уровня фрагментации политического пространства продолжится (“крупные” в электоральном отношении субъекты усилятся за счет “малых" с близкой идеологической ориентацией).

2. Несмотря на кажущиеся неустойчивость и непредсказуемость вектора изменения поддержки ведущих электоральных акторов, структура электорального пространства и распределение политических субъектов, принадлежащих к ключевым сегментам политико-идеологического спектра, в целом остается стабильной. Это обусловлено относительным постоянством состава социально-демографических групп, которые, собственно, и являются воплощением политико-идеологического размежевания в обществе. Речь идет о расколе между “сильными" и "слабыми": между группами приспособившихся к жизни в условиях формирующегося конкурентного общества "открытого" типа, и теми, кто не выдерживает конкуренции. В первом, самом общем "приближении” указанное размежевание актуализируется в положенном в фундамент данной работы крупнейшем “кливаже” социокультурного пространства России: "город - село".

3. Для электорального поведения горожан характерна известная самостоятельность в принятии решений, сельским же жителям свойственны конформизм и неспособность противостоять манипулятивным воздействиям со стороны властных структур. В наибольшей степени это различие проявляется в регионах, где задействован такой ресурс, как этническая мобилизация. “Ответом” городских избирателей на подобные попытки повлиять на их выбор зачастую становится протестное голосование против инициирующего их поли- 
тического субъекта (так было не только в республиканских центрах, но и в некоторых крупных городах “русских” краев и областей, где наблюдалась положительная динамика голосования за КПРФ).

4. Отмеченное сближение “красного" и “синего" политических пространств увеличение поддержки левых в городах “демократически” настроенных регионов и снижение ее в аграрных и сельских районах) стало результатом воздействия манипулятивных технологий и административного давления, просто на разные социальные группы они оказали противоположный эффект. При этом попрежнему сохраняется (в абсолютном выражении) преобладание поддержки на селе "левых" и "национал-патриотов", а в городах - реформаторских сил.

5. Ядра “левого” и “правого” электоратов чрезвычайно стабильны в своих политических предпочтениях. Фактор принадлежности к одной из этих электоральных субкультур является для их представителей главенствующим, оттесняя на второй план даже уровень социально-экономического благополучия (при сохранении дифференцирующей силы фактора политической позиции местной власти, с разным электоральным эффектом для обеих групп). Главным объектом предвыборной агитации выступает “центристский” деидеологизированный сегмент электорального пространства - в связи с "незаконченностью”, невыраженностью социально-демографического “облика" данной группы. Портрет такого избирателя эклектично сочетает в себе черты обоих полюсов размежевания, возникшего в посткоммунистическом обществе (“сильных" и “слабых" социальных групп). Именно такой избиратель, находящийся в поиске собственной социальной и идеологической идентичности, становится легкой добычей PR-технологов.

6. Оппозиция "город - село", будучи самым первым социологическим приближением к проблеме “сильных" и “слабых" групп в модернизирующемся обществе, естественно, не может объяснить все варианты поведения избирателей. Для повышения качества анализа необходимо привлечь к рассмотрению и другие социально-демографические характеристики. Чтобы реализовать эту исследовательскую задачу, следует создать статистическую базу, сочетающую социально-экономическую и электоральную статистику на уровне хотя бы избирательных округов.

K моменту выхода в свет настоящей статьи в России пройдут очередные, уже четвертые по счету, парламентские выборы. Тем интереснее будет проверить на новом эмпирическом материале валидность выявленных в ходе исследования тенденций и закономерностей электорального поведения избирателей в условиях продолжающейся социально-политической трансформации российского общества.

Весна-99: география и анатомия парламентских выборов. 1999. М.

Колосов В., Туровский Р. 1996. Электоральная карта современной России: генезис, структура и эволюция. - Полис, № 4.

Колосов В. и др. 1997. Поведение избирателей в России: теоретические перспективы и результаты парламентских выборов 1995 г. - Полис, № 4.

Овчинников Б. 2000. Электоральная эволюция: пространство регионов и пространство партий в 1995 и 1999 гг. - Полис, № 2.

Орлов Г., Шумпетов В. Модель электоральных предпочтений: методология построений. - Социс, № 1 .

Политический альманах России. 1997. М.

Регионы в 1999 г. Приложение к Политическому альманаху России. 2001. М.

Lazarsfeld P. et al. 1954. Voting: A Study of Opinion Formations in a Presidential Campaign. Chicago.

Lipset S.M., Rokkan S. 1967. Cleavage Structures, Party Systems and Voter Aligments. N.Y. 
ПРИЛОЖЕНИЕ 1.

ДИНАМИКА СРЕДНЕГО ПРОЦЕНТА ГОЛОСОВ И КОЭФФИЦИЕНТА КОРРЕЛЯЦИИ, РАССЧИТАННЫЕ ПО ОСНОВНЫМ "ПАРТИЙНО-ИДЕОЛОГИЧЕСКИМ" БЛОКАМ НА ПАРЛАМЕНТСКИХ ВЫБОРАХ 1995 И 1999 гГ. В ИЗБИРАТЕЛЬНЫХ ОКРУГАХ С РАЗЛИЧНОЙ ДОЛЕЙ ГОРОДСКОГО НАСЕЛЕНИЯ

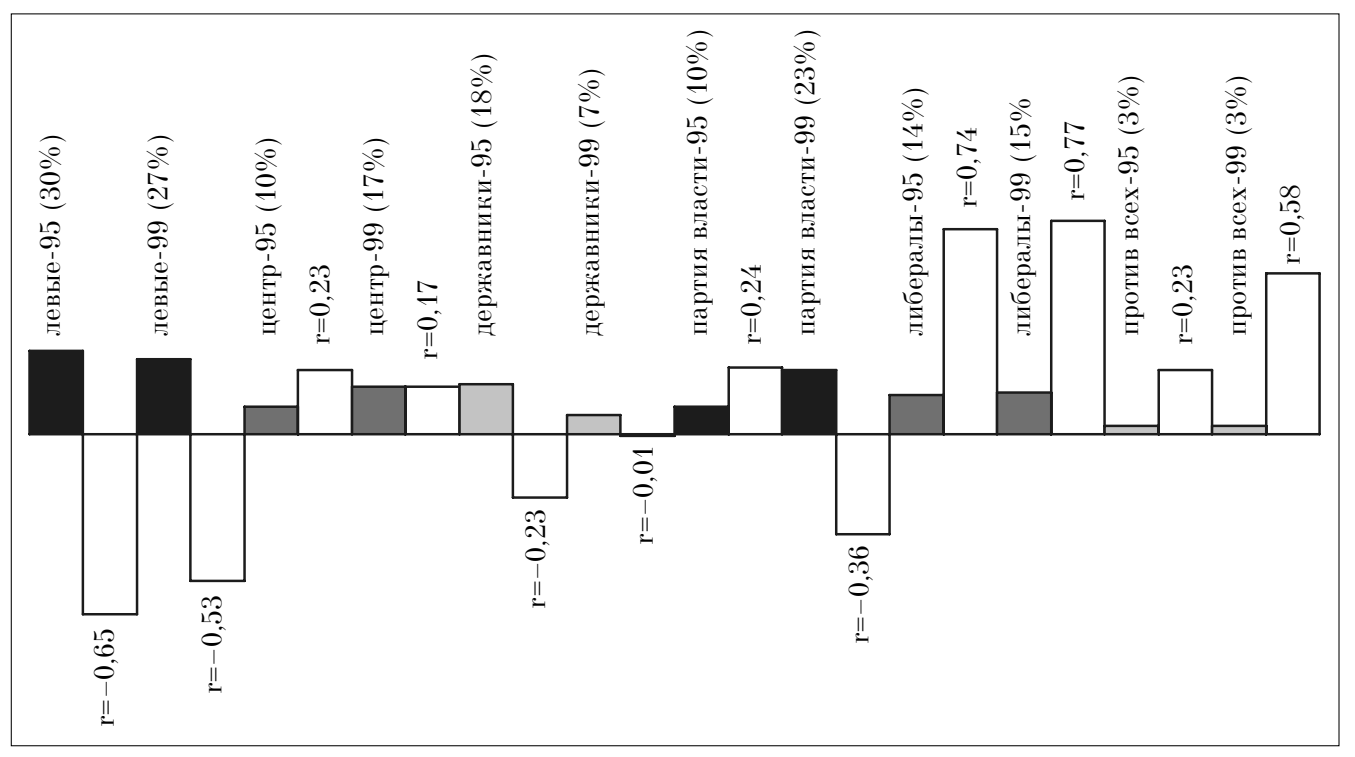

Puc. 1. Округа всех типов

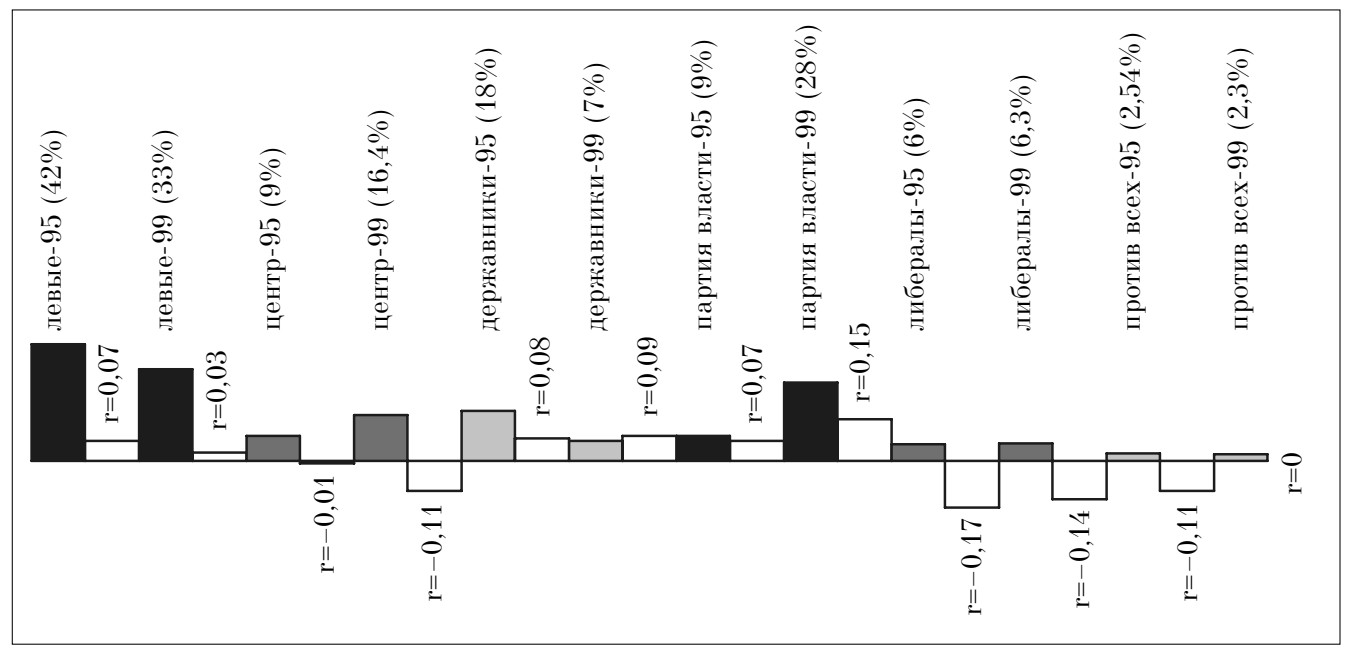

Puc. 2. Аграрные округа 
Vankov.qxd 07.12.2003 1:32 Page 100

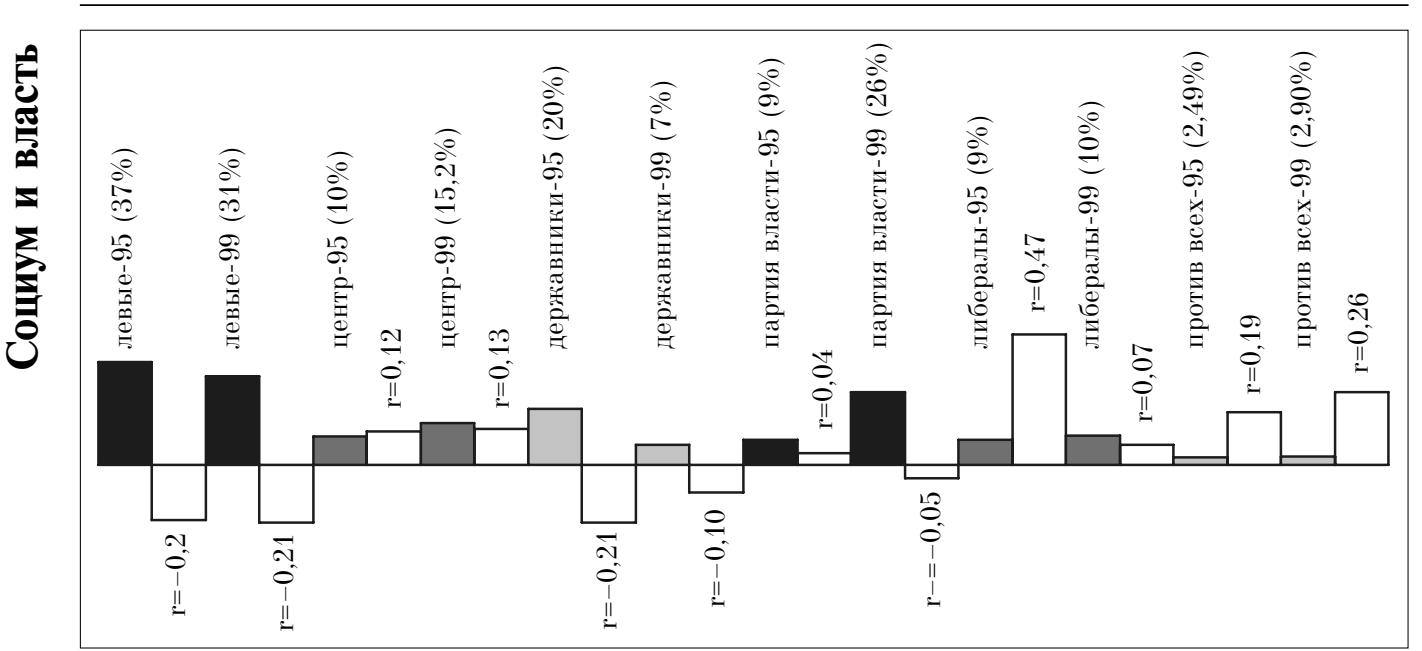

Рис. 3. Преимущественно аграрные округа

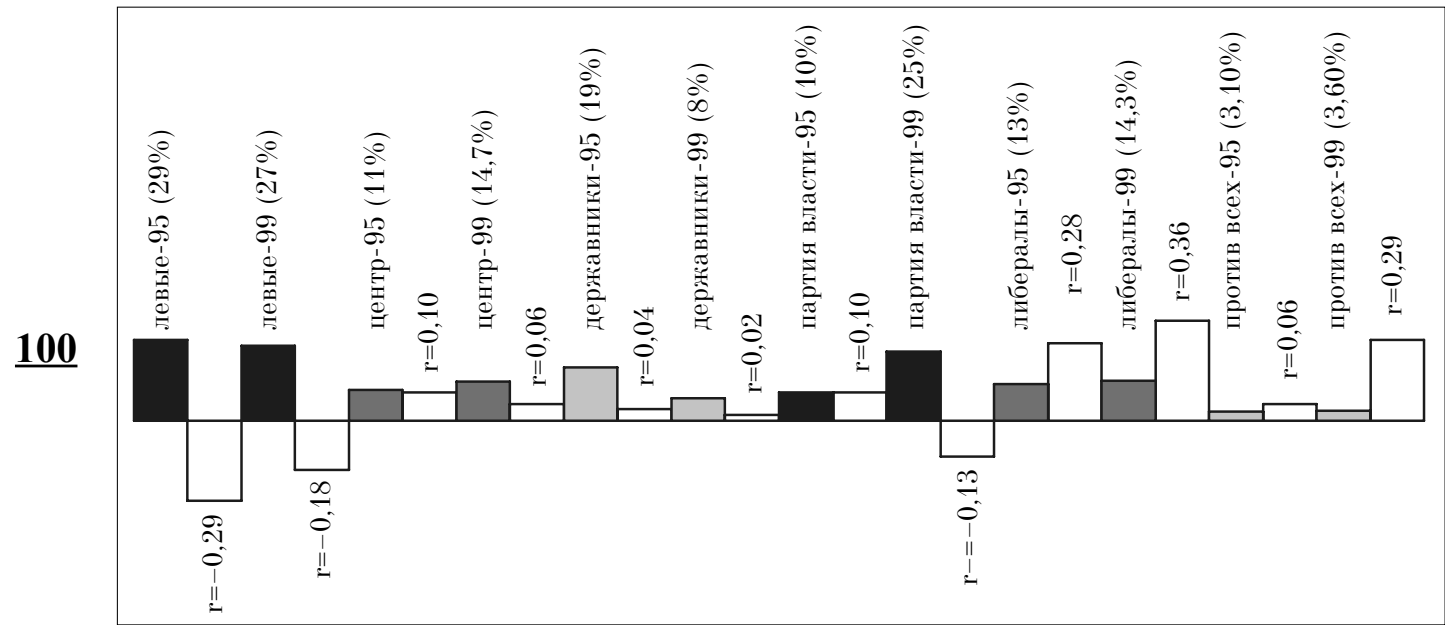

Puc. 4. Смешанные среднегородские округа

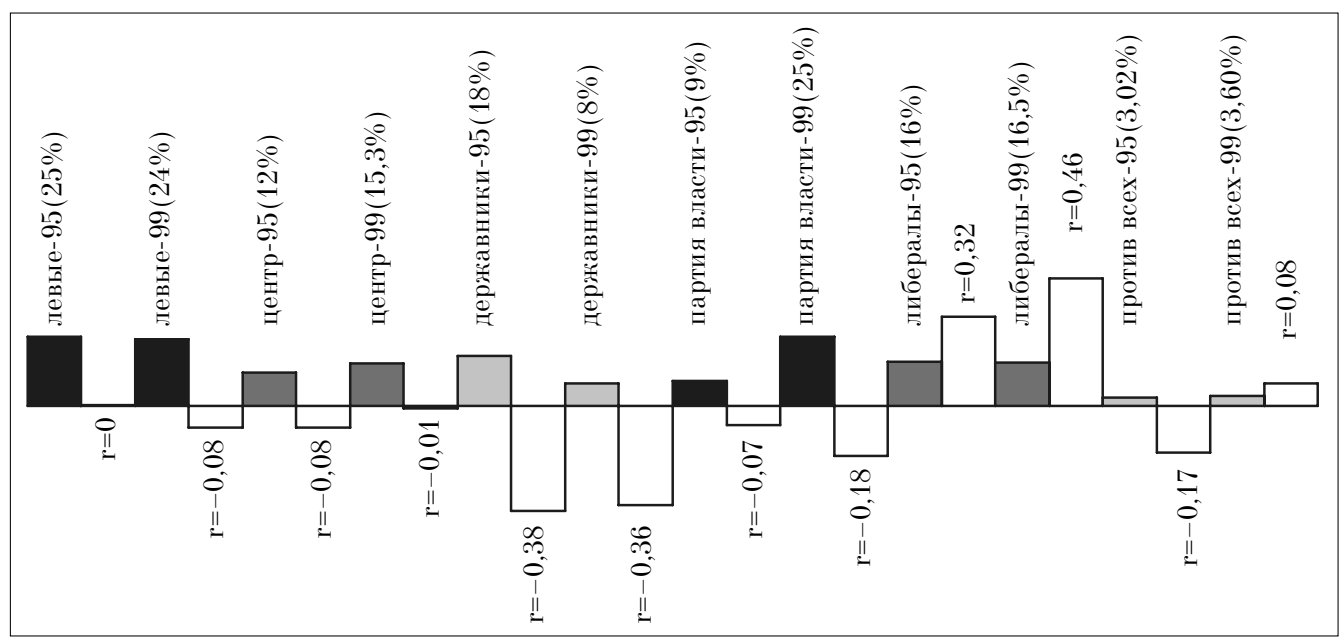

Puc. 5. Смешанные крупногородские округа 


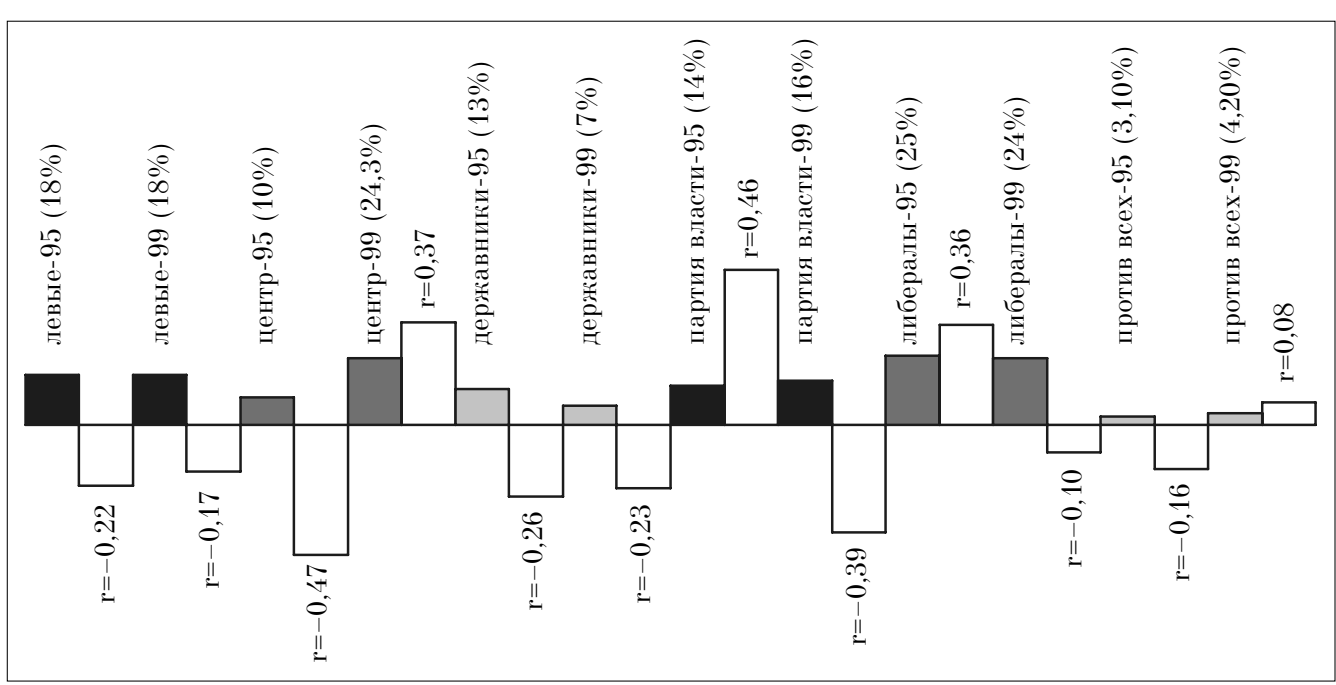

Puc. 6. Преимущественно городские округа

ПРИЛОЖЕНИЕ 2.

ДИНАМИКА СРЕДНЕГО ПРОЦЕНТА ГОЛОСОВ И КОЭФФИЦИЕНТА КОРРЕЛЯЦИИ, РАССЧИТАННЫЕ ПО ОТДЕЛЬНЫМ ПАРТИЯМ И ДВИЖЕНИЯМ

НА ПАРЛАМЕНТСКИХ ВЫБОРАХ 1995 И 1999 ГГ. В ИЗБИРАТЕЛЬНЫХ ОКРУГАХ

С РАЗЛИЧНОЙ ДОЛЕЙ ГОРОДСКОГО НАСЕЛЕНИЯ

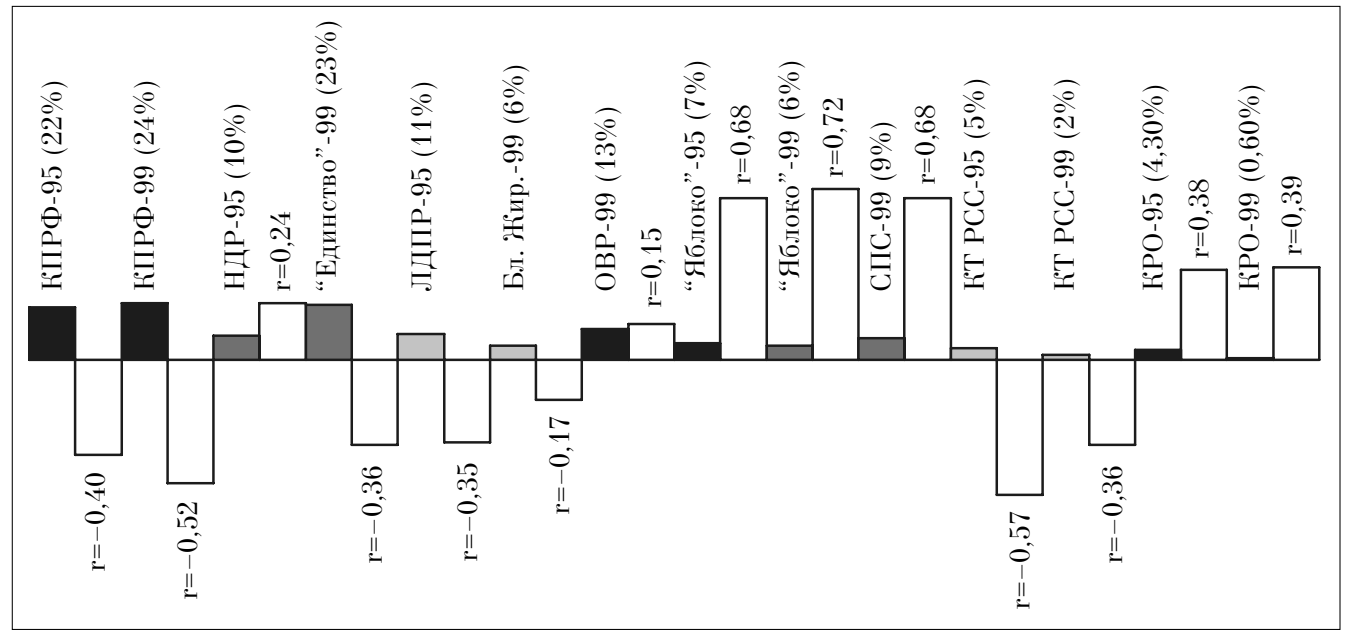

Puc. 1. Округа всех типов 


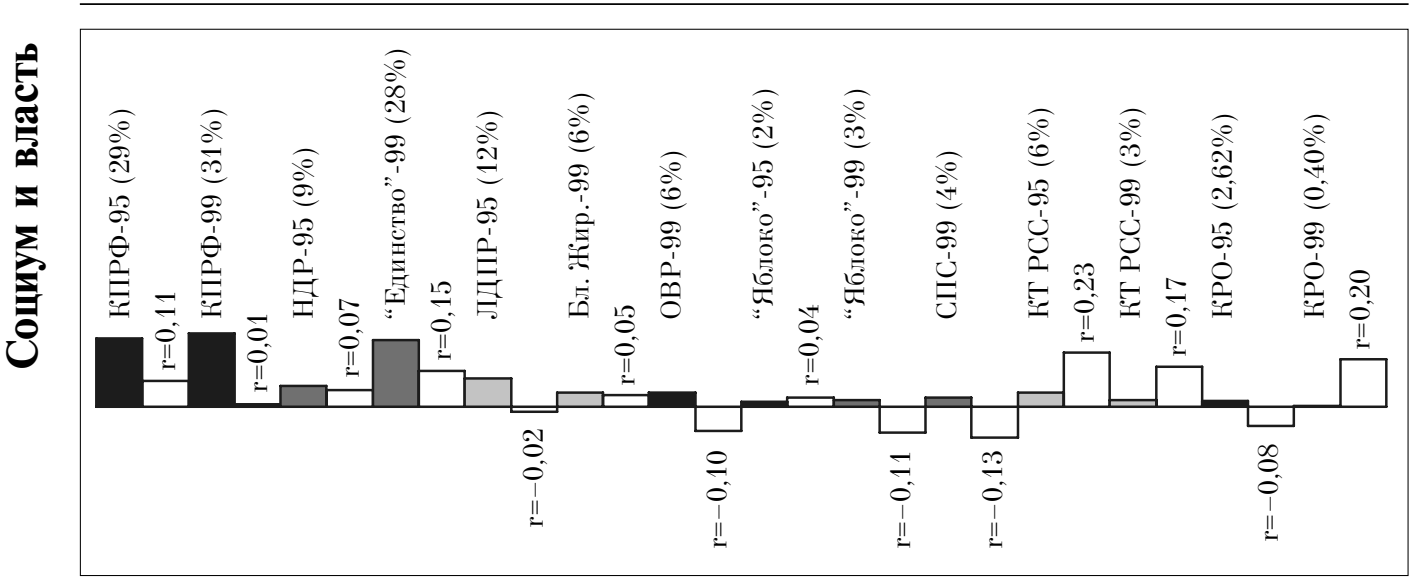

Рис. 2. Аграрные округа

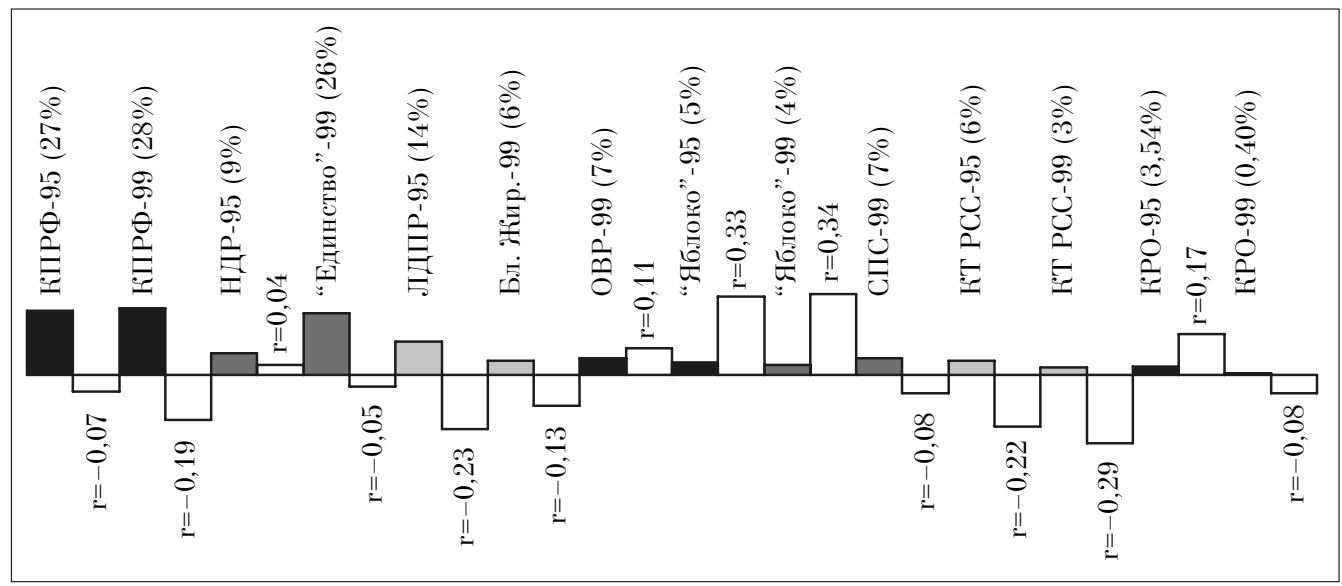

Puc. 3. Преимущественно аграрные округа

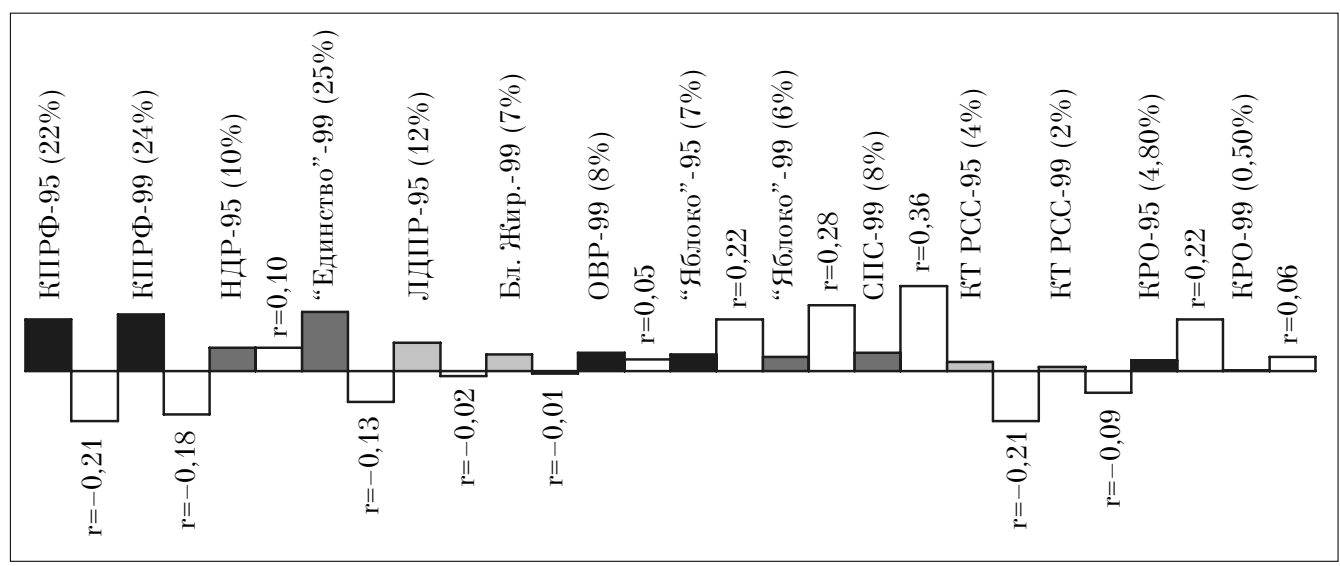

Puc. 4. Смешанные среднегородские округа 


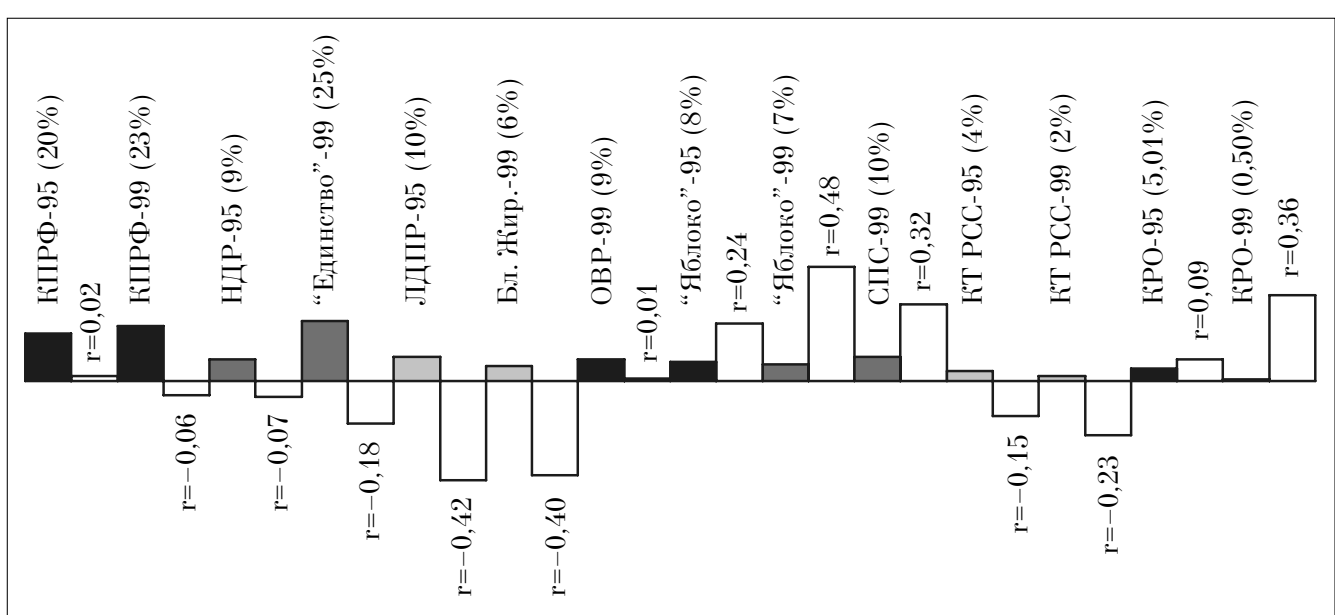

Puc. 5. Смешанные крупногородские округа

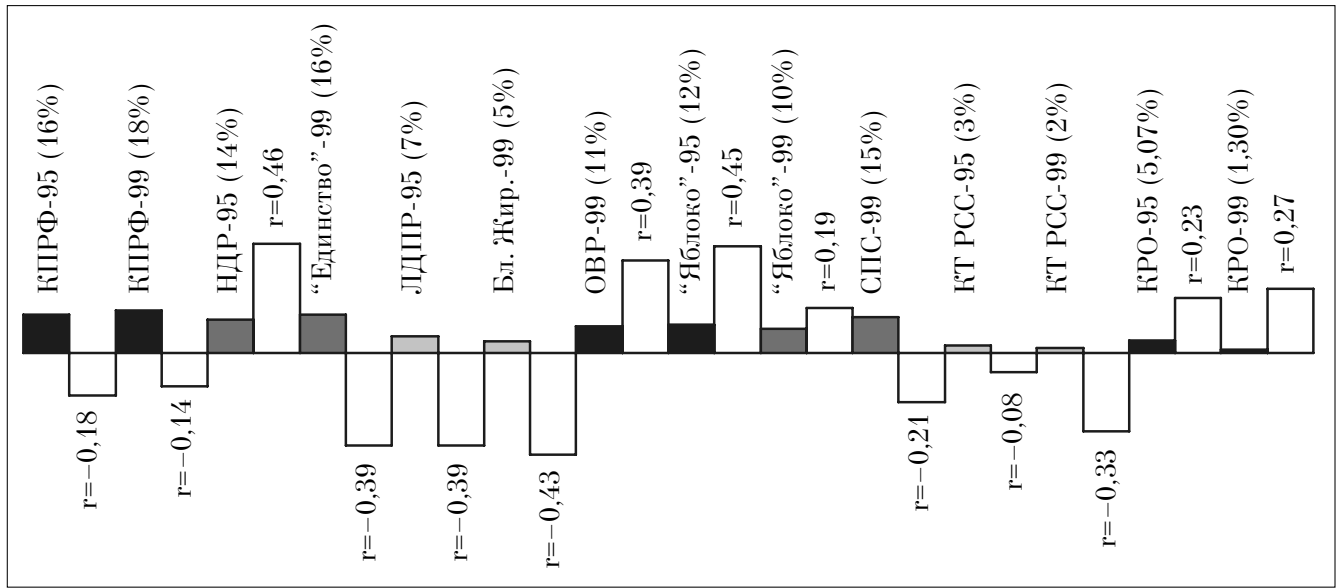

$\underline{103}$

Puc. 6. Преимущественно городские округа 